\title{
Debate: What Would be the Best Way to Use 10 Million Dollars in the Counter-Trafficking Sector?
}

\section{Matt Friedman}

For me, it is essential that the first question related to this query be: 'What are we really hoping to achieve with our available resources?' In the past, this question would have been answered in terms of the deployment of the traditional ' 3 Ps': prevention interventions, prosecution efforts and protection initiatives. Programme efforts under these headings are often designed to prevent people from being trafficked, put criminals in jail and help victims after they leave the exploitative environment. But few interventions explicitly state 'the goal is to reduce the number of people in human trafficking/slavery-like conditions'. The goal must be the reduction of overall victims.

The second question I would ask: 'What can be done to achieve the most impact in reducing the number of trafficked persons, with the least amount of resources?' In other words, I would seek to put in place a programme that is both cost effective and impactful. With limited funding available globally, every dollar must count.

The third question would be: 'Are there new or revised ways of addressing this problem?' In the past, a range of traditional approaches and partnerships has been used repeatedly. Yet, by any conceivable measure, many of these traditional approaches have not come close to reaching their full potential. For example, according to a range of evaluation reports, only a small proportion of victims are being helped to escape their situation and an even smaller number of traffickers have been brought to justice. To address the problem, innovative approaches need to be tested, refined and rolled out. This includes experimenting with bringing the private sector into the response in a very comprehensive manner. Like the criminals who engage in this illicit trade, the counter-trafficking community needs to be continuously evolving.

To begin the planning process, I would focus on the maths. According to the International Labour Organization (ILO), there are approximately 21 million people in human trafficking/slavery-like conditions today, ${ }^{1}$ of whom an estimated 11.7 million are in Asia. Thus, to get the greatest impact from this funding, I would target Asia, where the highest concentration of cases can be found, and focus on countries with the highest prevalence, namely India, China, Pakistan, Bangladesh or Thailand.

With $78 \%$ of victims in forced labour versus $22 \%$ in forced prostitution, ${ }^{2}$ I think it is important to concentrate on the former. Forced labour is where the greatest number of human trafficking victims can be found and where, with the right approach, we can potentially achieve the biggest reductions. For example, if the private sector is able to identify and address the problem of

${ }^{1}$ ILO, Special Action Programme to Combat Forced Labour (SAP-FL), ILO Global Estimate of Forced Labour 2012: Results and Methodology, June 2012.

${ }^{2}$ Of the forced labour, $10 \%$ is state-imposed, $68 \%$ is in the private sector. Ibid.

This is an open-access article distributed under the terms of the Creative Commons Attribution License (CC-BY). Under the CC-BY license, the public is free to share, adapt, and make commercial use of the work. Users must always give proper attribution to the author(s) and the Anti-Trafficking Review. 
human trafficking among a range of large manufacturing companies, many more victims can be identified than we are seeing in most sex trafficking raids.

Throughout Asia, there are a number of industries that are regularly associated with human trafficking, including the electronics, garment, seafood packing and fishing industries. Antitrafficking measures and governments in these countries and beyond need to focus on these industries. Acknowledging that each industry requires a unique response, however, I would first concentrate on only one to avoid diluting my efforts and wasting precious funding. The garment industry continuously receives attention in the news, so my ten-million-dollar programme efforts would directed towards this industry.

Of the countries listed above, China and Bangladesh have the greatest number of garment workers globally.

I would start with Bangladesh for the following reasons: I spent five years working there and have seen this problem first-hand in the garment industry; the country is relatively small; it has a strong track record of unions and civil society participation in development efforts; the government tends to be open to international support; the labour movement is flexible and active; and there have been a number of high-profile media stories on the garment industry over the past three years. At present, approximately four million people, mostly women, work in Bangladesh's USD 19 billion-a-year, export-oriented, ready-made garment industry. ${ }^{3}$

My next step would be to identify: (1) the extent of the problem in Bangladesh; (2) who is already working in the field; and (3) what the gaps are. I would do this by organising a six-week needs assessment at a cost of USD 50,000.

While the government has a central role to play in addressing forced labour within the garment industry, between its own resources and those supplemented by various United Nationssupported initiatives (ILO, International Organization for Migration (IOM), and United Nations Children's Fund) there are already efforts in place to develop and refine labour policies and provide capacity building and ongoing technical support. In addition, Bangladesh has a range of in-country and foreign non-governmental organisation/donor support in place and can expand union efforts across most manufacturing sectors. With these efforts already active, I would focus many of my resources on getting the private sector involved in the response-both inside and outside of Bangladesh. The activities would include:

- Awareness raising and training (USD 50,000): Carry out regular training of global corporations and their sub-contractors who source workers from Bangladesh to expand their general awareness and to sensitise them about the negative impacts of forced labour on their reputation. Much of the cost of this component can be covered by recipients of the training. In Hong Kong, this contribution has been demonstrated. The Mekong Club, a Hong Kong-based counter-trafficking organisation that works with the private sector (and in which the author plays a role), has been able to convince corporations to invest in audits and training activities for their supply chain staff.

- Third-party audits: Through the above general awareness and training initiative, I would demonstrate why brand-name companies need to conduct comprehensive third-party audits that will illuminate the real conditions faced by workers. These audits would go beyond the

\footnotetext{
${ }^{3}$ R Paul and S Quadir, 'Bangladesh urges no harsh measures over factory deaths,' Reuters, 4 May 2013, retrieved 27August 2014, http://www.reuters.com/article/2013/05/04/us-bangladesh-factory-idUSBRE94304420130504
} 
'soft tick' provided by many social auditing firms (the consequences of which have recently been made all too clear in Bangladesh) to take a proper look at labour conditions within supply chains from top to bottom, with specific emphasis on migrant worker conditions. Since this expense would be covered by the private corporations themselves, there would be limited outside funding required for this part of the project. The Mekong Club has trained over 5,500 people in 48 companies to understand the importance of auditing supply chains to help reduce human trafficking/slavery.

- Technical support to address exploitation in supply chains (USD 300,000): If issues were identified during the third-party audits, technical support would be offered to help garment contractors and sub-contractors to improve labour standards and conditions. In some extreme cases, the severity of the problem may warrant legal remedies and closure of the facility. Already there are examples in Bangladesh where better management has allowed companies to improve profits and raise worker standards simultaneously. The project would provide technical support using in-country labour specialists.

- Multi-stakeholder efforts (USD 50,000): As the project gains momentum, it would facilitate multi-stakeholder initiatives that link private sector business, workers, labour, civil society and governments to focus on a combined effort that brings the community together to achieve positive change.

The guiding principles for this effort would include: being as cost efficient as possible, understanding the problem, leveraging what already exists, getting partners to use their own resources (private sector), and placing emphasis on addressing the entire problem across the overall sector.

So back to the basic question of how to spend 10 million dollars. As we have seen with our efforts to fix other major public health and human rights issues, just throwing money at a problem is not usually the answer. In the fight to end human trafficking, I believe a lot can be done to address the issue without much funding. Sometimes we have to ask ourselves: 'Do we really need boatloads of money to make a difference?'

In the case of Bangladesh, much of what is proposed can be done with less than USD 500,000. But because of the scale of the problem there, the impact of this project could be substantial.

Just because we have ten million dollars does not mean we should spend it foolishly. Rather, we must be smart and systematic in the way we address this problem. Once we have identified and implemented programmes that have a demonstrated impact on the problem, we can then expand. A systematic and targeted approach within a comprehensive strategy, which does not just 'address' global slavery but actually reduces it, will ensure our limited resources are used to achieve our goal-reducing the number of victims in human trafficking/slavery-like conditions.

Matt Friedman is an international human trafficking expert with more than 25 years of experience as an activist, programme designer, evaluator and manager. He is currently the Chief Executive Officer for The Mekong Club, an organization of Hong Kong-based private-sector business people who have joined forces to fight human trafficking in Asia. From 2006 to 2012, Friedman was the Regional Project Manager of the United Nations Inter-Agency Project on 
Human Trafficking (UNIAP) in Thailand, an inter-agency coordinating body that links the United Nations system with governments and civil society groups in Cambodia, China, Lao People's Democratic Republic, Myanmar, Thailand and Vietnam. Prior to this (1991-2006), Friedman worked for the United States Agency for International Development (USAID) in Thailand, Bangladesh and Nepal.

Please cite this article as: M Friedman, 'What Would be the Best Way to Use 10 Million Dollars in the Counter-Trafficking Sector?', Anti-Trafficking Review, issue 3, 2014, pp. 157-162, www.antitraffickingreview.org 